\title{
Letter from chief editor
}

\author{
Suping Peng
}

Published online: 12 September 2014

(c) The Author(s) 2014. This article is published with open access at Springerlink.com

As a country with abundant coal, lean oil and scarce gas, China has been depended too much on coal. Coal accounts for about $66 \%$ (www.zgmt.com.cn) of primary energy consumption of China in 2013. China's raw coal output totaled 3.6 billion tons, but coal consumption approximated 4 billion tons, $47.4 \%$ and $50.3 \%$ of the world's gross coal output and consumption separately (www.BP.com). America, Australia, South Africa, Germany, Poland, Russia, India, Indonesia, Mongolia and Vietnam are also big coal producers. According to IEA projections, the world's coal production and consumption will continue to increase in the future 20 years. The production and use of coal couldn't be possible without successful efforts to study and solve a series of scientific and technological problems and to exchange and summarize the results, experiences and lessons in the research and engineering process. Journal of Coal Science \& Engineering (China), as the technological exchange platform on coal development, published by China Coal Society, already fails to address the current demands of domestic coal science \& technology circle. So it's urgent to shift the fields of academic exchange from the previous stress on coal exploration and development to coal conversion, efficient use and environmental protection.

After two years' preparation, this new journal: International Journal of Coal Science \& Technology (JCST), is established. This academic journal will be the first publication which focuses purely on one of the current crucial global topics, coal science and technology.

S. Peng $(\bowtie)$

Beijing, China

e-mail: psp@cumtb.edu.cn
JCST will publish original, high-quality, peer-reviewed research or review articles dealing with coal science and technology, mainly including:

- Coal geology, geophysics, geochemistry and exploration engineering, including formation and evolution of coal seam and basin, coal petrology, coal-related organic and inorganic geochemistry, mine engineering geology, mine hydrogeology, geophysical exploration method of coal and coal measure strata, and exploration and evaluation of gas resources in coal and coal seams. Besides, academic papers on the exploration and development of unconventional oil and gas resources with organic matter-rick are also welcome;

- Coal mining topics including rock mechanics, ground control, construction, roadway excavation and support, coal extraction, disaster prevention, green mining methods, top coal caving, fully mechanized coal mining technology for extra thick seams;

- Coal mine safety and environment, including coal seam gas prevention and control,mine fire prevention and control, mine safety monitoring technology,mine ventilation and dust control, development and utilization of coalbed methane; mining environment and reclamation, including impact of mining on environment; monitoring, prediction and assessment of land and environment; measures for minimization of environmental damage in mining areas; ecological restoration theory and technology; soil reconstruction and landscape reconstruction, contaminated land remediation, subsidence land reclamation and ecological restoration, surface mined land reclamation and ecological restoration, coal wastes management and 
ecological restoration, case study on mining reclamation and ecological restoration;

- Clean coal use and efficient conversion theory and technology, mainly including efficient coal preparation and beneficiation, combustion and conversion of coal, coal gasification, coal liquefaction, coal chemical products, as well as coal coking and comprehensive use of coal residues. The attention is focused on the clean coal technologies to control emission of pollutants like hazardous elements and reduce the emission carbon dioxide.

Many countries have attached great importance to safe and efficient development and clean utilization of coal over the past decade by making considerable investment in the scientific researches concerned. Therefore, when keeping track of the global research on coal science and technology, this journal will also make special reports on distribution characteristics of domestic coal resources, in-depth coal development, development of coal resources in arid and semi-arid areas, environmental and ecological self-restoration in the course of coal development, key technologies and equipment in efficient development of coal mines, direct and indirect coal liquefaction, and pollutant emission control of coal-fired power plants for the last two years. We hope the international scholars seize the latest research trends and contribute relevant papers. We'll give top priority to these papers.

The journal will be published quarterly. The first publication is a Special Issue on the clean coal technology, containing fifteen carefully selected research and review articles. These papers provide a cross-section of current research profiles of this sector.

The Special Issue begins with a series of research papers, falling into parts of clean coal utilization, coal conversion, geochemistry and mineralogy of coals. The first of these deals with the current hottest topic: particulate matter pollution $\left(\mathrm{PM}_{2.5}\right)$ control technology from coal-fired power stations (Wang et al.), the hybrid ESP/BAGs have the best elimination ability with an efficiency of over $99 \%$ not only for $\mathrm{PM}_{10}$ but also for $\mathrm{PM}_{2.5}$ and $\mathrm{PM}_{1}$. The authors made a calculation based on data from 2010 demonstrates that if hybrid ESP/BAGs are used by all power plants, total emissions can be reduced from 2.1836 million tons to 104.3 thousand tons, with a decrease of $\mathrm{PM}_{2.5}$ from 898.5 thousand tons to 47.48 thousand tons. It's followed by three analytical studies, including an analysis of minerals composition and occurrence modes in Late Permian coals from Zhenxiong Country, northeastern Yunnan of China (Li et al.), anomaly and geochemistry of rear earth elements and yttrium in the late Permian from the Moxinpo Mine, Chongqing of China were addressed by Jianhua Zou et al., and dissolution kinetics of $\mathrm{Si}$ and $\mathrm{Al}$ from montmorillonite in carbonic acid solution were investigated by Xiaoming Ni et al.
A group of articles describe different aspects of several coal conversion methods and utilization ways. A coal staged conversion poly-generation system based on fluid bed was researched and it could realize coal multi-product generation and has a great potential to increase coal utilization value $(\mathrm{Ni}$ et al.). An efficient directional direct coal liquefaction technology based on the maceral characteristics of Shenhua coal with higher oil yield and lower gas yield was developed (Shu and Zhang). Influence of catalytic systems on process of model object hydrogenation was discussed (Ispolovich et al.), followed by a simulation analysis of coal char gasification using high temperature and concentration $\mathrm{CO}_{2}$ produced by solid oxide fuel cells and oxy-fuel combustion ( $\mathrm{Li}$ et al.). Two papers are concerned with lignite, including one investigating the feasibility of applying forward and reverse combustion approach to the in situ gasification of lignite with production of hydrogen-rich syngas $\left(\mathrm{H}_{2}\right.$ and $\left.\mathrm{CO}\right)$ and the other studying the lignite desulphurization process via treatment by an oxidant (air or air-steam mixture) (Gunka and Pyshyev). As a clean utilization method for elements in coals, a kind of porous Sr-doped lanthanum manganite-yttria stabilized zirconia (LSM-YSZ) oxygen electrode was prepared by an infiltration process for reversible solid oxide fuel cell (RSOFC) and it exhibits high electrochemical performance and good stability (Fan and Han).

Following on from these research articles are four review papers. Two of them discussed the new advancement and findings, uncertainties and problems existing in dry coal beneficiation (Zhao et al.) and coal microwave desulfurization (Tao et al.); the other two articles overviewed the current status and technical challenges of $\mathrm{CO}_{2}$ storage in coal seams of enhanced coalbed methane recovery ( $\mathrm{Li}$ and Fang) and $\mathrm{CO}_{2}$ capture $\mathrm{RD} \& \mathrm{D}$ proceedings in China Huaneng Group (Wang and $\mathrm{Xu}$ ).

The editors would like to thank all of the authors who contributed papers to the Special Issue. These thanks are also extended to the authors of the papers that were submitted for inclusion, but for various reasons did not actually proceed to the publication stage. Through our publishing partnership, we aim to be the go-to resource for authoritative content and credible information on one of the greatest problems of our time. With its versatile conversion into liquid fuels, natural gas, and chemicals, the greater use of coal will help to build a healthier, wealthier and more energy-secured world.

\section{Chief Editor: Dr. Suping Peng}

Professor of China University of Mining \& Technology (Beijing)

Member of Chinese Academy of Engineering (CAE), Director of Energy Resources and Mining Department of CAE 
Member of National Energy Expert Consultation Committee

Member of Energy Resources Committee of Council of Academies of Engineering and Technological Sciences (CAETS)
Open Access This article is distributed under the terms of the Creative Commons Attribution License which permits any use, distribution, and reproduction in any medium, provided the original author(s) and the source are credited. 